\title{
Synthesis, Structural and Antioxidant Properties of $C$-p-methoxyphenylcalix[4]resorcinarene
}

\author{
Aishah Hasbullah $^{\# 1}$, Hamza.M.Abosadiya ${ }^{1}$ Jumina $^{2}$, M.Ibrahim M.Tahir ${ }^{3}$ and Bohari M Yamin ${ }^{1}$ \\ ${ }^{\# 1}$ School of Chemical Sciences and Food Technology, \\ Faculty Science and Technology, Universiti Kebangsaan Malaysia, \\ 43600 UKM Bangi, Selangor, Malaysia
}

${ }^{2}$ Chemistry Department, Universitas Gadjahmada, Indonesia, ${ }^{3}$ faculty of Science, Universiti Putra Malaysia, Serdang, Selangor. Malaysia. E-mail:aisah@ukm.my; hamza_inorg@yahoo.com; jumia@yahoo.com;Ibrahim@upm.my; bohari@ukm.my

\begin{abstract}
The structure of Calix[4]resorcinarene is less reported compare to other calixarene derivatives because of its conformational flexibility and stability when exposed to air. The presence of solvent molecules is important for its stability in the solid state. On the other hand, the presence of several phenol groups make it a good candidate for antioxidant study. Some of them have also shown good antibacterial activity. p-methoxyphenyl calix[4]resorcinarene was synthesized and characterized by infrared and $\left({ }^{1} \mathrm{H},{ }^{13} \mathrm{C}\right) \mathrm{NMR}$ spectroscopic techniques. After several attempts suitable crystals were obtained and with the help of a special oil an $X$-ray investigation was carried out at low temperature. The calix crystallized in triclinic system with space group Pī, a= 10.6958(5), $b=13.5781(7), c=16,3334(8) \AA, \alpha=68.284(4), \beta=74.275(5), \gamma=82.589(5)^{0}, Z=2$ and $V=2121.15(8) \AA^{3}$. The compound exhibits chair conformation with two resorcinol groups in anti-parallel position. The conformation is supported by eight DMSO and two DMF solvated molecules. It has a moderate antioxidant property.
\end{abstract}

Keywords - Calix[4]resorcinarene, p-methoxyphenyl and X-ray single crystal.

\section{INTRODUCTION}

Calix[n]arenes represent macrocyclic compounds are widely used in supramolecular chemistry for the construction of various receptors for the complexation of charged or neutral molecules [1]. Their unique threedimensional structures with almost unlimited derivatization abilities and a tuneable shape of the molecules make calixarenes ideal candidates for building blocks and/or molecular scaffolds in the design of new and more sophisticated molecules[2,3]. Calix[4]resorcinarene posses two hydroxy groups benzene rings at extra annular position that form the macrocycle nature have been synthesized generally by the acid-catalyzed cyclocondensation of resorcinol with various aliphatic or aromatic aldehydes [4]. The rapid development on these compounds was driven by their application as macrocyclic receptor, dendrimers in biological systems [5], nano-capsule [6], nano-particles [7] and optical chemosensors [8]. aithough the present calix has been reported the Cambridge Data base search gave no report on the molecular structure of the calix. It is known that most calix[4]resocinarene derivatives are not stable in the air and transforned into powder in a very short time.
Special effort is needed in order to collect the reflections within the experimental time. After several attempts a reasonable good data was obtained and the crystal structure of $\mathrm{p}$ methoxyphenyl calix[4]resorcinarene is reported to support the normal chemical characterisation data.

\section{METHODS}

\section{A. Chemicals and instrumentation}

Most of organic compounds utilized in this research were commercial products of high purity purchased from Acros and Sigma and used as such without any further purification.

The microelemental analysis, CHNS-O was carried out by using Carlo Erba 1108. The infrared spectra (IR) of the products were recorded by using the Perkin Elmer Spctrum GX spectrophotometer in the range $400-4000 \mathrm{~cm}^{-1}$. Nuclear Magnetic Resonance (NMR) for ${ }^{1} \mathrm{H}$ and ${ }^{13} \mathrm{C}$ experiment were performed with Joel ECP $600 \mathrm{MHz}$ in $\mathrm{d}_{6}$-DMSO as solvent. $\mathrm{X}$-Ray data were collected at the low temperature with Oxford instrument at Universiti Pitra malaysia spectrometer using Mo K $\alpha$ radiation $\left(\lambda=0.71073 \mathrm{~A}^{\circ}\right)$. 


\section{B. Preparation of C-p-methoxyphenylcalix[4]resorcinarene}

$7 \mathrm{ml}$ of concentrated hydrochloric acid was added into a round-bottom flask containing a solution of4-Anisaldehyde $(0.01 \mathrm{~mol}, 1.36 \mathrm{gm})$ in absolute ethanol $(60 \mathrm{ml})$. The solution mixture was stirred for 30 minutes and a solution of resorcinol $(0.01 \mathrm{~mol}, 1.101 \mathrm{gm})$ in absolute ethanol $(20 \mathrm{ml})$ was added to the mixture. The mixture was refluxed for 10 hours at $80^{\circ} \mathrm{C}$. The purple precipitate was collected by filtration, washed with distilled water and acetone several times. The colorless crystals were obtained by recrystallization of the precipitate in DMSO suitable for Xray analysis in good yield $(74.23 \%, 1.23 \mathrm{gm})$.

FTIR $\left(\mathrm{KBr}, \mathrm{cm}^{-1}\right): 3399.92(\mathrm{OH}), 2998.01$ ( $\mathrm{CH}$ aromatic), $2835.99\left(\mathrm{OCH}_{3}\right), 1608.71$ and $1510.51(\mathrm{C}=\mathrm{C}$ Aromatic $) ; \delta_{\mathrm{H}}$ (600 MHz; DMSO) 3.69 (3H, s, $\left.\mathrm{OCH}_{3}\right), 5.57$ (CHmethine bridge $), 6.12\left(2 \mathrm{H}, \mathrm{s}, \mathrm{CH}_{\mathrm{Ar}}\right), 6.53\left(2 \mathrm{H}, \mathrm{d}, \mathrm{J}=8, \mathrm{CH}_{\mathrm{Ar}}\right), 6.60$ $\left(2 \mathrm{H}, \mathrm{d}, \mathrm{J}=8, \mathrm{CH}_{\mathrm{Ar}}\right), 8.51(2 \mathrm{H}, \mathrm{s}, \mathrm{OH}) ; \delta_{\mathrm{C}}(600 \mathrm{MHz} ; \mathrm{DMSO})$ $55.1\left(\mathrm{OCH}_{3}\right), 102.3(\mathrm{CH}$-methine bridge $), 112.9\left(2 \times \mathrm{CH}_{\mathrm{Ar}}\right)$, $121.2\left(2 \times C \mathrm{H}_{\mathrm{Ar}}\right), 129.8\left(2 \times C \mathrm{H}_{\mathrm{Ar}}\right), 138.2\left(2 \times C_{\mathrm{Ar}}\right), 152.9(2$ $\left.\mathrm{x} C_{\mathrm{Ar}}\right), 156.9\left(2 \times C_{\mathrm{Ar}}\right)$; Anal Calculated for the compound $\left(\mathrm{C}_{56} \mathrm{H}_{48} \mathrm{O}_{12}\right): \mathrm{C}=73.67$ and $\mathrm{H}=5.30$, Found: $\mathrm{C}, 73.08$ and $\mathrm{H}, 4.89$.

\section{Antioxidant studies}

A stock solution of DPPH was prepared by dissolving $0.4 \mathrm{gm}$ of DPPH in $1 \mathrm{~L}$ methanol and the solution was kept in the dark at $4 \mathrm{C}^{\circ}$. A stock solution of the $C-p$ methoxyphenylcalix[4]resorcinarenewas prepared at 10 $\mathrm{mg} / 5 \mathrm{ml}$ in DMSO. $100 \mu \mathrm{l}$ from the stock solution of the compound was added to the $1 \mathrm{ml}$ of DPPH (Abos:1.012nm). The mixture was shaken well and kept in dark at room temperature for 2 hour. The absorbance of the mixture was measured at $517 \mathrm{~nm}$ by using spectrophotometer (Abos: $0.33 \mathrm{~nm}$ ). The present inhibition of radical scavenging ability was calculated as:

$\%$ inhibition $=\left[\left(\mathrm{A}_{\mathrm{DPPH}}-\mathrm{A}_{\text {Sample }}\right) / \mathrm{A}_{\mathrm{DPPH}}\right] * 100=[(1.012-$ $0.33) / 1.012]^{*} 100=67.39 \%$

\section{RESULTS AND DISCUSSION}

The FTIR spectrum of calix showed characteristics absorption at $3399.92 \mathrm{~cm}^{-1}$ corresponds to O-H stretching vibration. A much weaker band at $2998.01 \mathrm{~cm}^{-1}$ is for the C$\mathrm{H}$ stretching frequencies. The peak at $2835.99 \mathrm{~cm}^{-1}$ is typical of a methoxy group on an aromatic ring and the $\mathrm{C}=\mathrm{C}$ aromatic ring appeared at $1510.51 \mathrm{~cm}^{-1}$.

The ${ }^{1} \mathrm{H}$ NMR assignment for the calix was straightforward. The $\mathrm{OH}$ group of resorcinol ring was assigned at $8.51 \mathrm{ppm}$. The appearance of singlet multiplicity signal indicated that this hydroxyl has a same chemical environment. A two doublet peaks at 6.54 and $6.60 \mathrm{ppm}(\mathrm{J}=$ 8 ) are well defined peak assignable for equal amount of the aromatic linkager protons. Two $\mathrm{C}-\mathrm{H}$ aromatic resorcinol displayed a singlet at $6.11 \mathrm{ppm}$, a singlet at $5.57 \mathrm{ppm}$ for methine bridge and another singlet at 3.69 was assigned for methoxy proton. (Fig. 1)

\section{X-Ray Crystallography study}

$\mathrm{X}$-ray investigation showed that the compound crystallized in triclinic system with space group of Pĩ. The unit cell dimension are $a=10.6958(5), b=13.5781(7)$, $c=16,3334(8) \AA, \alpha=68.284$ (5), $\beta=74.375(4) . \gamma=82.579(4)^{0}$, $\mathrm{Z}=2$ and $\mathrm{V}=2121.15(8) \AA^{3}$. The crystal system and refinement parameters are given in Table 1 .

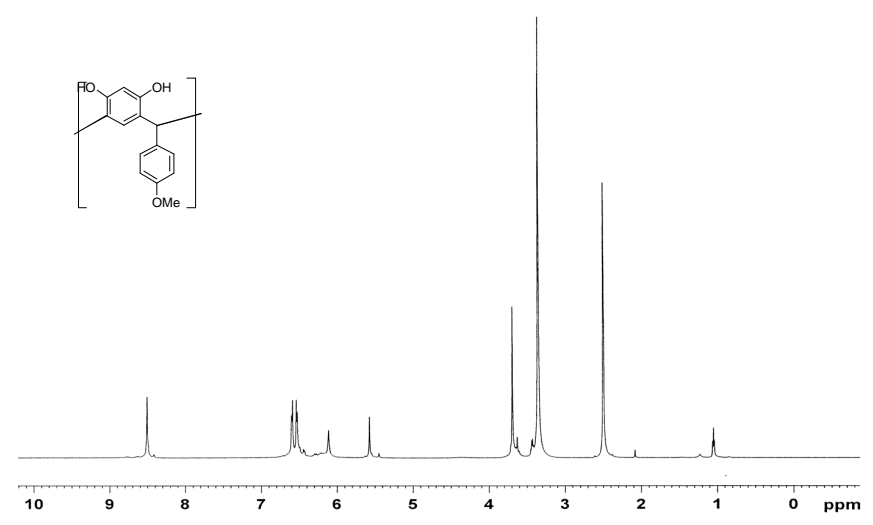

Fig. 1. ${ }^{1} \mathrm{H}$ NMR spectrum of $C$-p-methoxyphenyl calix[4]resorcinarene in $\mathrm{d}_{6}$-DMSO,

TABLE I

CRYSTAL DATA AND STRUCTURE REFINEMENT FOR $C$-pMETHOXYPHENYLCALIX[4]RESORCINARENE

\begin{tabular}{|c|}
\hline $\mathrm{C}_{78} \mathrm{H}_{110} \mathrm{~N}_{2} \mathrm{O}_{22} \mathrm{~S}_{8}$ \\
\hline Formula weight \\
\hline Temperature \\
\hline Wavelength \\
\hline Crystal system \\
\hline Space group \\
\hline $\mathrm{a}=10.6958(5) \AA \mathrm{b}=13.5781(7) \AA$ \\
\hline $16.3334(8) \AA, \alpha=68.285(5)^{\circ}, \beta=74.375(4)$ and $\gamma=82.579(4)^{\circ}$ \\
\hline Volume \\
\hline $\mathrm{F}(000)$ \\
\hline $0.3 \times 0.36 \times 0.42 \mathrm{~mm}^{3}$ \\
\hline Theta range for data collection 3.00 to $71.58^{\circ}$. \\
\hline $\begin{array}{l}\text { Index ranges } \\
13<=\mathrm{h}<=13,-16<=\mathrm{k}<=16,-19<=1<=19\end{array}$ \\
\hline Reflections collected \\
\hline Independent reflections \\
\hline Completeness to theta \\
\hline Full-matrix least-squares on $\mathrm{F}^{2}$ \\
\hline Data / restraints / parameters 8144 / 0 / 503 \\
\hline Goodness-of-fit on $\mathrm{F}^{2}$ \\
\hline Final $\mathrm{R}$ indices $[\mathrm{I}>2 \operatorname{sigma}(\mathrm{I})] \quad \mathrm{R} 1=0.1356, \mathrm{wR} 2=0.4627$ \\
\hline $\mathrm{R} 1=0.1403, \mathrm{wR} 2=0.4767$ \\
\hline $\begin{array}{ll}\text { Extinction coefficient } \quad 0.0000(7) \\
\end{array}$ \\
\hline Largest diff. peak and hole 3.974 and -2.802 e. $\AA^{-3}$ \\
\hline
\end{tabular}

The asymmetric unit consists of one $C$-pmethoxyphenylcalix[4]resorcinarene at special position with centre of inversion, eight DMSO and two DMF molecules of crystallization (Fig.2). The $\mathrm{N} 1$ and $\mathrm{O} 11$ atoms are 
disordered and were not treated. The calix[4] moiety adopts a chair conformation. The two pairs of apposite resorcinol rings are coplanar and a pair of it is antiparallel.

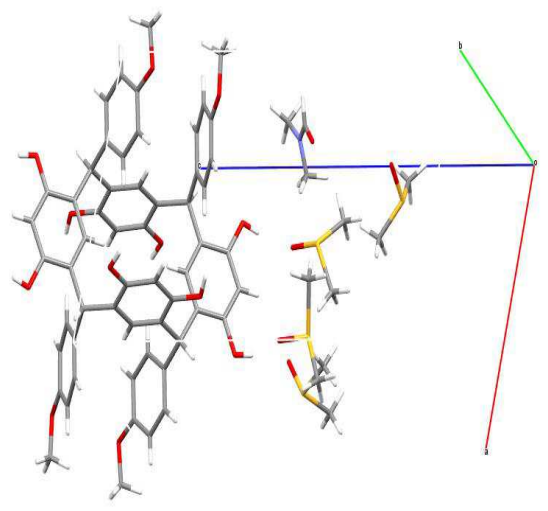

Figure 2. .The asymmetric unit of $C$-p-methoxyphenyl calix[4]resorcinarene

The calix molecule adopts a chair conformation with two apposite resorcinol groups are almost coplanar to each other but a pair of them is in the anti-parallel position

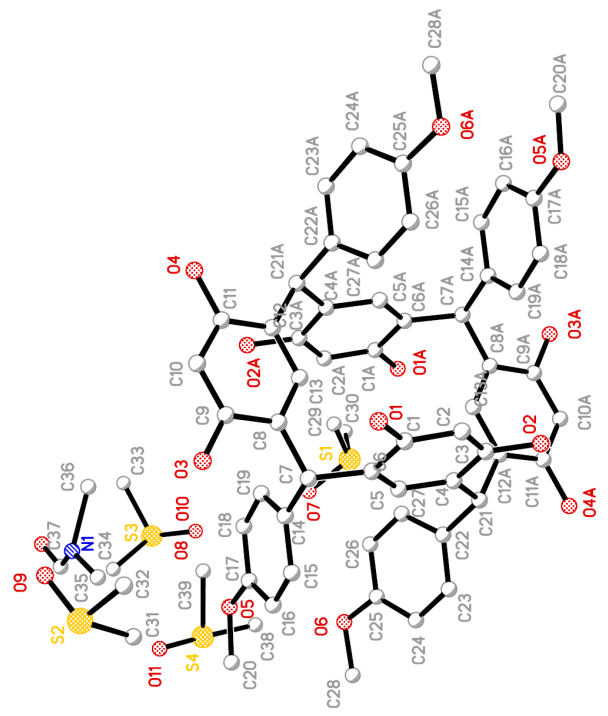

Figure 3. The molecular structure of $C$-p-methoxyphenyl calix [4]resorcinarene drawn at $50 \%$ probability ellipsoid., The hydrogen atoms were omittrd for clarity.

The opposite resorcinol rings are perfectly planar as indicated by the clean NMR spectrum. The dihedral angle between the alternate (C1-C6) and (C8-C13) resorcinol rings is $77.7(2)^{\circ}$ whereas with the lingkage benzene ring (C14$\mathrm{C} 19)$ is $85.1(2)^{\circ}$. The two methoxyphenyl linkage groups that attached to the coplanar resorcinol rings are at the opposite directions but the two groups attached to the antiparallel resorcinol rings are in the same directions. Similar conformation with approximately $\mathrm{C}_{2 \mathrm{~h}}$ symmetry due to the presence of crystallographic inversion center was also observed for tetraarylboronic acid resorcinarene[9]. The bond lengths and angles are in normal ranges and comparable with other resorcinarene[10] . The structure is stablized by extensive O-H...O, O-H...S, and C-H...O intermolecular hydrogen bonds.

\section{Antioxidant properti}

Antiradical properties of $C$ - $p$-methoxyphenyl calix[4]resorcinarene was monitored by the decrease in absorbance of 1,1-diphenyl-2-picrylhydrazyl radical (DPPH). Calix[4]resorcinorene which can donate hydrogen atoms to the non-radical form of DPPH is highly efficient antioxidant agents [11]. The free radical scavenging activity of $C$-p-methoxyphenyl calix[4]resorcinarene of $67.30 \%$ is a moderate antioxidant and comparable to $5,11,17,23$,tetra-ter-butyl-25,27-bis(5-(henyl)-1,3,4-oxadiazole-2thiacarbonylmethoxy)-26,28-dihydroxycalix[4]arene[12].

\section{CONCLUSION}

The $C$-p-methoxyphenyl calix[4]resorcinarene has been synthesized and fully characterised by FTIR and NMR techniques. The X-ray crystallographic data were obtained to support the structural study despite the instability of the crystal upon exposure to the air. It showed a moderate antioxidant.

\section{ACKNOWLEDGMENT}

The authors thank the Ministry of Higher Education of Malaysia and UniversitiKebangsaan Malaysia for the research grant IMPAK PERDANA-2012.. One of the authors HMA would like to thank the Ministry of Higher Education of Libya for the scholarship.

This document is a template. An electronic copy can be downloaded from the conference website. For questions on paper guidelines, please contact the conference publications committee as indicated on the conference website. Information about final paper submission is available from the conference website.

\section{REFERENCES}

[1] Gutsche CD. Calixarenes revisited. Cambridge: Royal Society of Chemistry; 1998. (b) Mandolini L, Ungero R, editors. Calixarenes in actions. London: Imperial Collage Press; 2000.

[2] Vicens J, Bihmar V. Calixarenes. A versatile class of macrocyclic compounds. Dordrecht, The Netherlands: Kluwer Academic Publisher; 1991.

[3] De Silva AP, Fox DB, Huxley AJM. CoordChem Re view; 2000; 41:41.

[4] Timmerman P, Verboom W and Reinhoudt D N, Tetrahedron, 1996, 52, 2603.

[5] Benedetti E, Pedon C, Iacovino R, Botta B, DelleMonach G, De Rosa M C, Botta M, Corelli F, Taft A and Santini A, J Chem Research (s), 1994, 476.

[6] Botta B, Iacomacci P, Di Giovanni C, Delle Monach G, Gacs-Baitz E, Botta M.Taft A, Corelli F and Misti D, J Org Chem., 1992, 57, 3259.

[7] Hedidi M, Hamdi S M, Mazari T, Boutemeur B, Rabia C, Chemat F and Hamdi M, Tetrahedron, 2006, 62, 5652.

[8] Thoden Van Velzen E U, Engbersen J F J and Reinhoudt D N, J Am Chem Soc., 1994, 116, 3597.

[9] Davis C. J., Lewis. P. T. Billodeaux. D. R. Fronczek. F. R,.Escobedo J. O, and Strongin R. M, 2001 Solid-State Supramolecular Structures 
of Resorcinol-Arylboronic Acid Compounds. Organic letters Vol. 3,No 16 2443-2445

[10] Alshahateet. S. F, Kooli. F, Messali. M, Judeh .Z. M. ElDouhaibi. A S, 2007 Synthesis and Supramolecularity of CPhenylcalix[4]Pyrogallolarenes: Temperature Effecton the Formation of Different Isomers Taylor \& Francis Group, LLC ISSN: 15421406 print $=1563-5287$

[11] Vovk.I A , Shivanyuk .M. A , Bugas .V.R, Muzychka V.O, Melnyk A.K.(2009), Antioxidant and antiradical activities of resorcinarene tetranitroxides. Bioorganic \& Medicinal Chemistry Letters 19 (2009) 1314-1317.

[12] Patel, M., Modi, N.R., Raval, J.P. and Menon, S.K.(2012)

Calix[4]arene based 1,3,4-oxadiazole and thiadiazole derivatives: Design, synthesis and biological evaluation. Org. Biomol Che., 10. 1785-1794. 